pelo caso de inspetores, é uma coisa de bater muito. É uma norma que converice, claro,no nivel do geral, mas tem que achar um sentido prá isso dentro da instituição como um todo, nāo só na funçăo dele.

"O PSICÓLOGO DEVE ASSUMIR QUE TEM PODER"'

Cenise: $O$ que pode dizer o técnico ao funcionário é: que outras coisas a gente poderia estar fazendo por essas pessoas? Porque se são violentas, isso é uma forma de comunicaçâo delas e vaj ser sempre assim se a gente não of erecer outro meio delas se comunicarem. Numa época, numa colonia feminina, nós faziamos reuniões gerais, com pacientes, funcionários, técnicos, todo mundo, para discutir problemas, as coisas que tinham acontecido, coisas práticas como a televisāo que tinha quebrado e era um problema porque demorava prá consertar, etc. Antes, a pessoa que quebrou a televisão era punida, ia para a cela forte - A gente observou num primeiro momento que os pacientes propunham normas muito rigidas - como o cara nunca mais poder assistir televisāo, nunca mais sair da cela forte - entāo tinha que fazer com que eles ficassem mais flexíveis. Eles vāo interiorizando toda a rigidez institucional e não conseguem ver outro canal, tanto os pacientes como os funcionários. Falta esse espaço prá discussão, prá compreensão, essa flexibilidade.

Outra coisa importante sobre a instjtuição é que a gente só descobriu a violência dentro do mundo do cárcere depois da repressão política, quando alguns jovens da classe média foram torturados. Só aí se descobriu que a violência era muito antiga, que sempre houve mas nảo fazia parte do nosso cotidiano. Isso foi muito atacado pelo rádio, pela televisāo, um exemplo é que quando o PMDB assumiu o poder em S. Paulo houve toda uma denúncia da situação do Juqueri e veja como ele está hoje. Não se fala mais nada, então onde é que está a mudança dentro da instituiçào? No nível de governantes, eles também sabem disso e só se vai tocar no assunto de novo quando for mudar o governo. Majs ou menos em 81 , quando houve uma rebelião no Juqueri e a Rota entrou lá e matou sete pessoas, se falou muito nisso. Hoje não se fala mais nada e o Manicômio está na mesma.

Yara: $O$ discurso inicial do governo em relação ao Manicômio, à Febem, ao projeto do menor, era muito mais avançado do que tem sido a prática. Tinha a proposta de acabar com a violência, transformar a Febem e hoje a única mudança que eu vejo é a desinternação, uma coisa numérica tàmbém.

O psicólogo deve assumir que tem poder, que pode mudar alguma coisa, apesar de tecnicamente nāo lidar com elementos muito concretos, palpáveis. Em alguns momentos fica mais fácil se desincumbir de qualquer comprometimento e dizer que não tem poder nenhum e que isso o impe. de de opinar, quando deve. Existe aí uma omissão.

\title{
Delírio delinqüente: a educação pela violência
}

\author{
Maria da Graça Ferraz e Ferraz \\ Professora da Faculdade de Psicologia da Unesp \\ Campus de Assis - SP
}

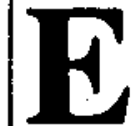
sse campo em que trabalhei foi escolhido em funçāo do tema ndo propriamente da violência mas das relaçóes de poder: as distâncias sociais entre as pessoas, nāo só dentro daquele espaço mas no contexto de toda uma influência sofrida por essa instituição específica, a $E B$ - Escola da Barra.

Essa escola nasceu de uma forma muito peculiar porque já era, de inicio, um "ato infrator". Seus fundadores eram ex-operários que conseguiram fazer um curso superior e decidiram abrir a escola como forma de oferecer, aos filhos de operários e d população mais carente da periferia de São Paulo, condiçôes de estudar.

$A$ fundação da $E B$ foi $\mathrm{um}$ ato político, um protesto ativo contro um estado de coisas que se vivia na época. Esse grupo de professores invadiu uma fabrica abandonada, colocou algumas cadeiras, uma lousa e uma placa informando que ali funcionaria um curso supletivo de 10 grau. Os alunos foram aparecendo, a escola comecou a crescer, recebendo alunos de uma grande parte da periferia de São Paulo. Funcionou quase dois anos na ilegalidade, eles náo sabiam o que precisava ser feito para oficializar o diploma dos alunos, se o curso poderia ser reconhecido mais tarde, nada se sabia.

De certa forma a fundação dessa escola foi um ato de violéncia contra o poder instituido, contra o ensino oficial. Os professores nāo estavam preocupados com o que se ensinava fora de lá e talvez esse tenha sido o erro do grupo, näo participar um pouco da realidade de fora. A ignorancia do contexto social político e económico nāo ajuda nada.

Era uma atitude violenta, delinqüente e geradora de violência, que eu chamo "delírio delinqüente". Todas as coisas aconteciam na porrada, eles ignoravam que existia toda uma estrutura social que tinha de ser considerada como interferente nesse processo e nāo negada. Todo o processo de aprendizado era, por parte dos professores, uma tentativa de querer criar ali uma nova microestrutura, um mundo modelo que funcionasse melhor do que o mundo de fora. Eles transcendiam demais o processo de ensinar e aprender.
Essa postura, que tinha muito a ver com o rancor, o ressentimento por parte dos professores e alunos carentes contra o que eles chamavam de burguesia, passou a ser criadora de situaçós de desatino. Nao pagavam dívidas que tinham com empresas, como por exemplo, a fornecedora de papéts para a gráfica da escola: chegavam os cobradores $e$ eles diziam que não tinham dinheiro, que as empresas näo faziam mais do que a obrigação em ajudar na educaço da populaçäo carente, etc. Houve casos de credores enfurecidos, que pagaram marginais para invadir a escola e receber o dinheiro a força. Esse clima de violência foi criando complicaçöes cada vez maiores.

E essa violéncia era valorizada, no topo da hierarquia estavam os delinquentes. Existiam quadrilhas inteiras interessadas em estudar. Era incrivel ver a vontade de saber deles. Eram muito interessados $\mathrm{em}$ filosofia $e$ os professores ndo reprimiam nada que se fizesse, podiam falar o que bem entendessem, sem aquele esquema rigido de disciplina. Era uma escola livre, nesse aspecto era uma coisa muito bonita, criativa, que poderia ter dado muitos frutos.

\section{"O que eu podia fazer, como psicóloga, para essas pessoas carentes de comida, de saúde?}

Acho que existia uma ideologia dentro da escola que era mais ou menos assim: o poder continua, só temos que trocar as pessaas que o exercem. Por isso, os delinquentes no poder $e$, ao lado deles, a classe operária. A escola funcionou inclusive como refúgio de bandidos, adolescentes que tinham se prostituido eram acolhidos, para que, segundo o "chefe", näo continuassem na prostituiçăo.

A minha relação com tudo isso era assim: no começo eu fui extremamente marginalizada, era como sc eu fosse a infratora, pela minha condição de "in. telectual burguesa", bem-alimentada, que estava ali porque näo tinha mais nada para fazer. Se eu quisesse participar de fato, tinha de botar a māo na massa, ajudando a construir a escola e ndo falando sobre ela. O trabalho intelectual era totalmente desvalorizado. 


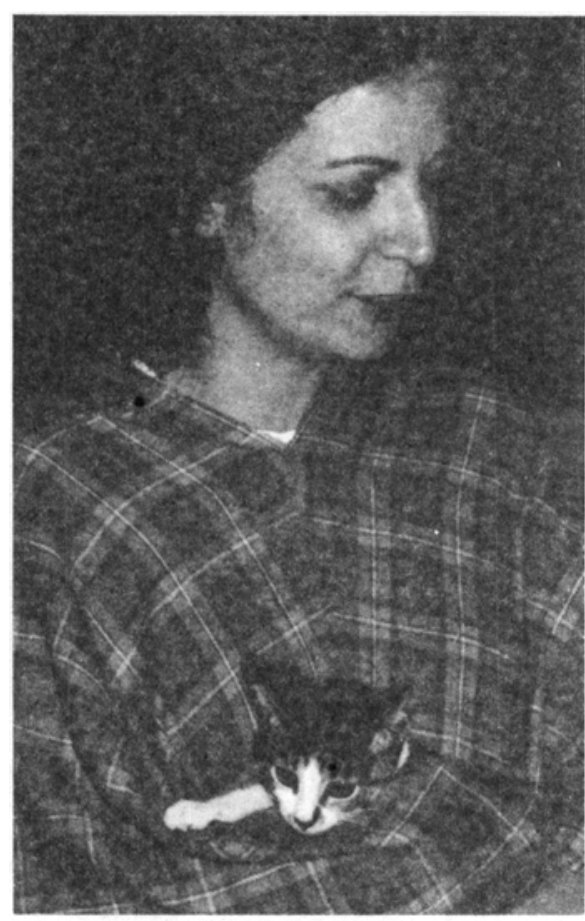

Maria da Graça Ferraz

Eles me perguntavam, que pesquisa é essa? Para quê? Eu dizia que estava tentando levar um trabalho social, uma coisa que a gente chamava de pesquisaçâo, mais militante, prática; mas de qualquer forma eles me cobravam, o que eu podia fazer como psicóloga, para essas pessoas carentes de comida, de saúde? Para dizer a verdade nem eu sabia o que podia ser feito.

Num contexto de aula, numa universidade, é fácil dizer que nāo se sabe o que é ser psicólogo e que se está tentando descobrir Esse tipo de coisa so dá pra processar com pessoas que tenham a mesmo tipo de dúvida, a mesmo referencial $-E$ para aquelas pessoas você dizer que nāo sabe o que é Psicologia Social é se queimar demais. Eu sabia apenas que aquilo tudo me seduzia, me fascinava. Percebi que estava investindo todo o meu desejo naquilo, eu queria falar disso e cont ecer aquelas pessoas. O convivio, o jeit ? dos alunos, o tipo de paquera, de chegar e passar uma cantada, tudo era extrema. mente sedutor.

Eu queria saber o que era aquele grupo de professores, ex-operários, trabalhadores braçais que inventaram um projeto intelectual, eu queria saber o que era isso na cabeça deles, como entendiam essa coisa e paraque. Mas no fundo, eles também não sabiam o que estavam querendo. No correr do processo,eles percebiam que ndo era bem do jeito que eles queriam, porque existia uma força social muito forte, contrária a essa corrente. Porque se você dá pau. lada, você recebe paulada. Era o que eles estavam fazendo, estavam caminhando desatinadamente contra um pelotāo de fuzilamento.

Como pesquisadora, eu queria entender as relaçōes de poder ali dentro, mas como psicóloga ell também nāo sabia o que dava para ser feito. Eu descobri que a unica forma de levar adiante a pesquisa era me enfronhando, na pratica mesmo, e trabalhando como qualquer outra pessoa de lá. Eles me cobravam um trabatho braçal e eu acabei fazendo de tudo, desde varrer chão até atender na cantina, dar aulas, funcionar como psicóloga, orientadora educacionat etc., eu arregacei as mangas $e$ trabalhei.

\section{"O que me aproximava da Escola era essa vontade de liberdade"}

Eusentia neles uma vontade muito grande de liberdade, de existir além das normas sociais, de uma moral instituida, de formas de existência social que ja estavam reificadas na sociedade. Ali desembocavam todos os tipos de pessoas que de alguma forma nóo se ade. quavam ao convivio social. Eram advogados que nāo conseguiam sucesso na profissdo e acabavam dando aulas e sendo advogados da Escola, diretores que tinham sido demitidos dos cargos e assumiam a direçāo lá, professores aposentados que nao faziam mais nada da vida. Inclusive eu, que no começo não sabia o que queria direito. $E$ fui percebendo que o que me aproximava da Escola era essa mesma vontade de liberdade, de existir fora das restriçóes. Eu posso dizer que me sentia muito violentada, $e$ vi que aquelas pessoas também se sentiam assim. A minha simples presença era uma lembrança da violência social que elas sofriam, de dominador intelecual principalmente, aquele que tem know-how, que detém um saber competente, um saber que é poder. Marilena Chaut e Foucault pare ce que tem algo sobre isso. Os professores se sentiam muito mal perto de mim, como se eu tivesse ali para avaliar o processo, para dar um feed-back, para ver se o que estavam fazendo era certo ou errado. Eu, na mesma medida, me sentia mal de perceber o quanto era rejeitada, o quanto estava identificada com meu papel no contexto social; era vista como ociosa, alguém que náo realiza o trabalho braçal e portanto näo merece repartir os ganhos da produçato. Eu não tinha direito a nada, sequer dar uma opinido, era sempre educadamente cortada. Quando ia falar alguma coisa, eles cortavam dizendo que eu náo sabia nada daquilo, só sabia quem tinha pas. sado fome, trabalhado duro. Uma vez, a primeira em que ful procurar agua, näo encontrei filtro, nem geladeira e fui perguntar para alguém como eles toma. vam agua; me respondeu que tomavam da torneira, eu retruquei que era perigoso, entäo ele falou que eles ndo ficavam doentes nunca, eles apenas morriam de fome mesmo...

$\mathrm{Na}$ minha tese eu resolvi nâo reve. lar a identidade de ninguém por causa dos riscos aue a escola corria. Se revelasse algumas coisas que eu via aconte. cerem, tudo poderia ficar muito perigoso. Os professores mandavam os alunos invadirem colégios caros de SP para roubarem microscópios, materiais de laboratório, coisas caras que a Es. cola nāo ia poder comprar nunca. Fol muito gostoso, mas foi também muito sofrido fazer o que eu fiz, principalmen. te porque eu estava muito desarmada nisso de saber o que é ser psicóloga, psicóloga social, dentro da realidade brasileira.

O mais importante nesse trabalho foi perceber o quanto é impossivel se ter formulas de como fazer, de como ser psicóloga social. A minha dúvida é co. mo dar um parecer sobre a prática, porque no fim acaba-se fazendo juizo de valor, apesar de todo o cuidado.

$O$ importante foi perceber que dentro da EB existia um jeito, o meu jeito de ser psicóloga, que talvez até fosse parecido com o de outros psicólo. gos que convivessem com aquilo. Em cada lugar é diferente, um jeito singular que é criado dentro de cada contexto. que nasce da sua articulaçáo com a prática. Nâo adianta ter uma porçāo de teorias, de coisas prontas para en caixar porque näo dá certo. A prótica nasce engajada na situaçāo, extremamente articulada ao processo. Tive a oportunidade de entender que aquilo era mais do que a oportunidade de tes. tar teorias, coisas que disseram que estavam certas.

Muitas vezes senti vontade de in. terromper o trabalho, de parar $e$ me questionar, para que estou fazendo tu. do isto, que utilidade tem? No verdade, até hoje nâo sei da utilidade que isso possa ter para alguém. Eu fui lá, vi e vivi tudo aquilo, senti a violência na propria pele; morria de medo de ir pra casa às II da noite, de esperar o onibus no ponto da Barra Funda - e a própria clientela da escola tinha medo, sempre muito assustadas -, mas no fim aca. bei fazendo amizade com alguns bandidos maiores, que se ofereciam para me acompanhar até em casa para me proteger. Eu e meu marido dávamos aulas la nessa época. Na verdade, para mim, - importante mesmo foi perceber que năo sabia nada. Que tudo aquilo que tinha pronto na cabeça nào servia pra me dar o rótulo de dominadora, que era o fantasma contra o qual o grupo todo da $E B$ lutava. 